\title{
Pemasangan feeding plate dan ikatan ekstra oral pada bayi celah bibir dan langit-langit bilateral komplit disertai premaksila protrusif
}

\author{
The utilization of feeding plate with extra oral strapping in infant with complete \\ bilateral cleft lip and palate with protrusive premaxilla
}

\author{
Lisda Damayanti \\ Bagian Prostodonsia \\ Fakultas Kedokteran Gigi Universitas Padjadjaran \\ Bandung, Indonesia
}

\begin{abstract}
Cleft lip and palate abnormalities in infant are the most common birth defect. This abnormality caused by failure of the fusing at the middle side of the facial frame on the week 4 to 10 of pregnancy. This abnormalities may occur together or separately. The coordination of the lip, tongue, palate and jaws become inadequate so there is changes in the ability to suck, to swallow, weak muscle function and oral structure function so that the infant maybe unable to suck properly. Feeding plate use to overcome disproblem, so that the infant can have good nutrition. In infant with complete bilateral cleft lip and palate with protrusive premaxilla the utilization of this feeding device with the strapping extra oral rubber elastic orthodontic and hypapix is sure. In this paper will be discuss the utilization of device with the addition elastic orthodontic rubber in patient with complete bilateral cleft lip and palate. This feeding intervention is quiet effective, the sucking reflects of the infant become stronger and the premaxilla profile becomes more retruded that makes the surgeon get an optimal surgical result easier.
\end{abstract}

Key words: cleft lip and palate, feeding plate, protrusive premaxilla

\begin{abstract}
ABSTRAK
Kelainan celah bibir dan langit-langit pada bayi merupakan kelainan yang paling sering ditemukan. Hal ini disebabkan karena kegagalan penyatuan kerangka wajah bagian tengah yang terjadi pada minggu keempat sampai dengan minggu kesepuluh masa kehamilan. Kelainan ini dapat berdiri sendiri atau kombinasi keduanya. Koordinasi bibir, lidah, langitlangit dan rahang menjadi tidak sempurna sehingga terjadi perubahan kemampuan mengisap, menelan, tipe tekanan dan fungsi struktur mulut yang menyebabkan bayi kesulitan dalam mengisap susu. Feeding plate digunakan untuk mengatasi keluhan pada bayi celah bibir dan langit-langit sehingga memudahkan bayi dalam proses menyusu untuk memenuhi asupan nutrisi. Pada kasus celah bibir dan langit-langit dua sisi lengkap dengan premaksila yang protrusif, pemakaian piranti dilengkapi dengan ikatan ekstra oral pemasangan karet elastik ortodonti dan hypafix. Pada studi kasis ini dilaporkan mengenai pemasangan feeding plate dan ikatan ekstra oral pada bayi celah bibir dan langit-langit bilateral komplit disertai premaksila protrusif. Penggunaan alat ini sangat efektif, refleks mengisap bayi menjadi lebih kuat dan profil premaksila menjadi lebih mundur sehingga membantu dokter bedah untuk memperoleh hasil operasi yang maksimal.
\end{abstract}

Kata kunci: celah bibir dan langit-langit, feeding plate, premaksila protrusif

Koresponden: Lisda Damayanti, Bagian Prostodonsia, Fakultas Kedokteran, Gigi Universitas Padjadjaran, Bandung, Indonesia, E-mail:lisda.raiha@yahoo.com

\section{PENDAHULUAN}

Pada bayi baru lahir yang mengalami celah bibir dan langit-langit akan menghadapi kesulitan dalam menyusu, yaitu tidak efisiennya pengisapan saat menyusu dan kemungkinan susu masuk ke saluran napas sehingga menyebabkan bayi tersedak serta air susu keluar melalui hidung. Selain itu, waktu yang dibutuhkan untuk menyusu lebih lama sehingga perut bayi kembung, tidak nyaman serta kebutuhan nutrisi tidak terpenuhi. Adanya celah menyebabkan kemampuan bayi untuk menutup rongga mulut dan mengisap, tidak adekuat sehingga bayi tidak mampu menarik cairan ke dalam mulut secara efisien. ${ }^{1}$ Kelainan orofasial memiliki potensi untuk mengubah kemampuan mengisap, menelan, tipe tekanan dan fungsi struktur mulut yang terlibat dalam proses asupan makanan pada bayi. ${ }^{2}$

Pembentukan isapan intra oral pada bayi yang mengalami celah bibir dan langit-langit terganggu oleh ketidakmampuan bayi membentuk penutupan anterior yang memadai dengan menggunakan bibir dan ketidakmampuan untuk menutup rongga mulut inferior akibat celah langit-langit bilateral, sehingga bayi sulit untuk menekan puting di antara lidah dan langit-langit. Pada celah langit-langit terdapat akses antara rongga mulut dan rongga hidung dalam menempatkan makanan dan sekresi oral berada di dekat rongga eustachia. Keadaan ini mengarah pada tingkat kejadian otitis media kronis yang tinggi pada bayi penderita. ${ }^{1}$ 
Perawatan dini harus diberikan kepada bayi yang baru lahir yang mengalami dengan celah bibir dan langit-langit karena fungsi alami dari daya isap dan penelanan yang menjadi sulit sehingga terjadi masalah dalam pemberian susu dan pertimbangan pertumbuhan kraniofasial yang cepat pada 12 bulan pertama, terutama 12 minggu pertama. Lengkung rahang yang lebih normal yang terbentuk pada usia dini akan mempengaruhi perkembangan struktur tulang wajah, dan cenderung menghasilkan pola pertumbuhan yang normal. Pada bayi yang segmen premaksilanya menunjukkan pergeseran ke depan, rangkaian perawatan meliputi konstruksi feeding prosthesis dengan modifikasi penempatan ikatan ekstra oral untuk mengembalikan posisi segmen yang bergeser. ${ }^{3}$ Untuk itu, pada studi kasis ini dilaporkan mengenai pemasangan feeding plate dan ikatan ekstra oral pada bayi celah bibir dan langitlangit bilateral komplit disertai premaksila protrusif.

\section{KASUS}

Bayi A, laki-laki lahir dengan usia cukup bulan dengan berat badan 3,0 kg. Setelah serangkaian pemeriksaan ekstra dan intra oral, terlihat kelainan dengan diagnosis celah bibir dan langit-langit bilateral komplit disertai premaksila protrusif (gambar 1). Ibunya selama masa hamil menyangkal menggunakan obat-obatan, jamu atau mengalami trauma.

\section{PENATALAKSANAAN}

Bayi dikonsul ke Rumah Sakit Hasan Sadikin (RSHS) Bandung. Setelah dilakukan pemeriksaan secara menyeluruh, dilakukan pencetakan pada usia bayi 29 hari di ruang COT. Dua hari berikutnya dilakukan pemasangan feeding plate di ruang Poli Gigi dan Mulut oleh residen Prostodonsia RSHS disertai instruksi kepada orang tua bayi mengenai cara pemasangan, pelepasan dan perawatan piranti tersebut.

Kontrol pertama dilakukan 1 minggu setelah piranti dipasang, serta dipantau kesehatan umum, kenaikan berat badan bayi $(3,4 \mathrm{~kg})$, refleks isap (+), retensi alat $(+)$, iritasi di permukaan rongga mulut (-). Dua minggu kemudian dilakukan kontol kedua, berat badan bayi $3,7 \mathrm{~kg}$, kesehatan umum baik, retensi piranti $(+)$, refleks hisap $(+)$, pemasangan ikatan ekstra oral, dan penambahan bahan tissue conditioner di bagian permukaan anatomis anterior premaksila (gambar 2). Tiga minggu berikutnya pada kontrol ketiga,berat badan bayi menjadi $4,2 \mathrm{~kg}$ kesehatan umum bayi menampakkan demam dan batuk, juga dilakukan penambahan bahan tissue conditioner di bagian permukaan anatomi anterior
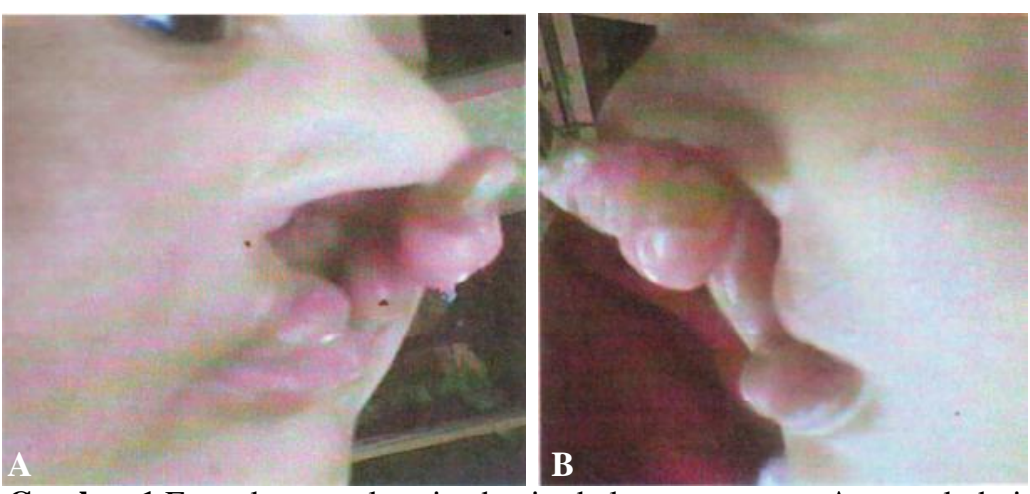

Gambar 1 Foto ekstra oral pasien bayi sebelum perawatan, A tampak dari kanan, $\mathbf{B}$ tampak dari kiri.

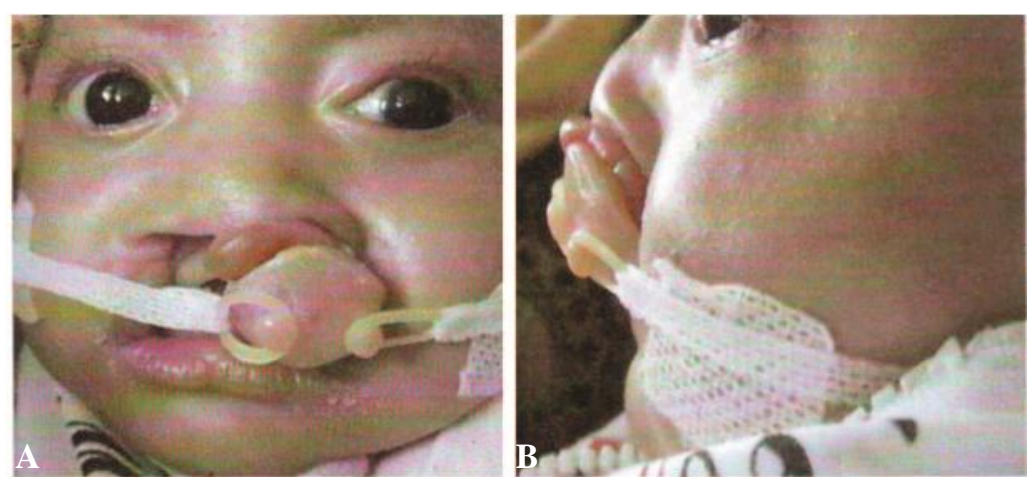

Gambar 2 Foto ekstra oral pasien bayi setelah pemasangan button dan elastik pada feeding plate pada kontrol kedua, A tampak dari depan, B tampak dari kiri. 

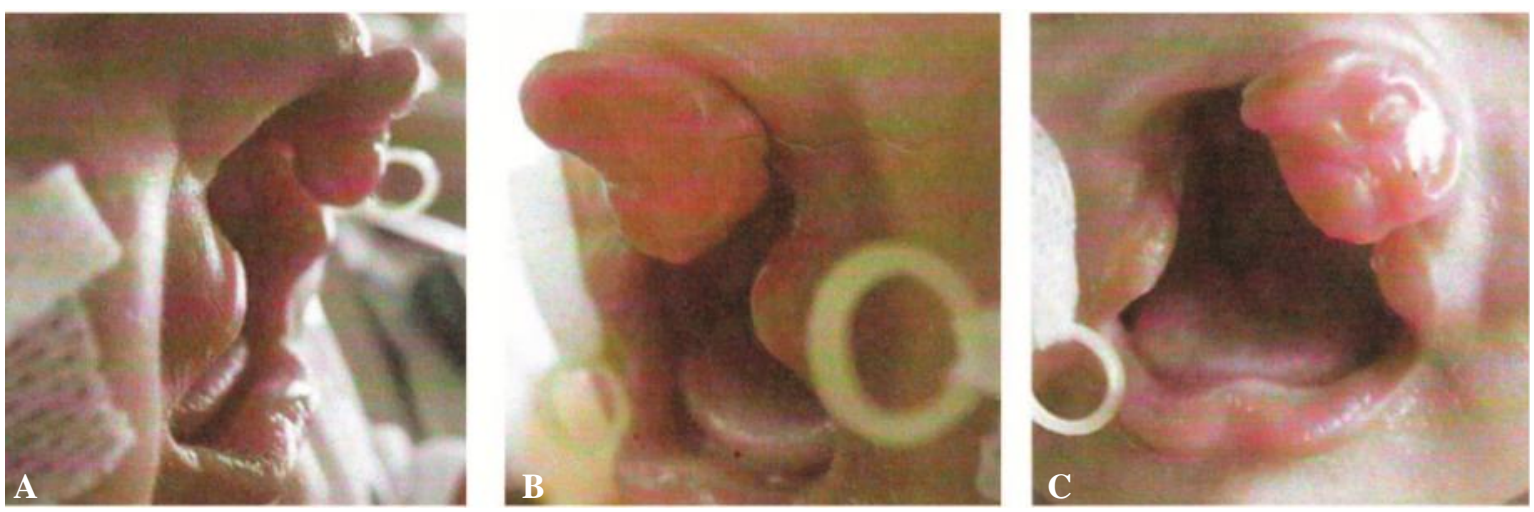

Gambar 3 Foto ekstra oral pasien bayi setelah kontrol ketiga, A tampak dari kanan, B tampak dari kiri, dan C tampakan dari depan.

premaksila (gambar 3) dan dikonsul ke Poli Anak RSHS.

Tiga minggu berikut, pada kontrol keempat, berat badan bayi menjadi $4,5 \mathrm{~kg}$, kesehatan umum baik, aktivasi ikatan ekstra oral untuk mengarahkan premaksila mundur dan ke arah sisi kanan bayi. Pada kontrol kelima, empat minggu berikutnya, berat badan bayi $4,9 \mathrm{~kg}$, penambahan soft liner di bagian anatomi anterior dan lateral kiri premaksila. Dua minggu kemudian pada kontrol keenam, berat badan $5,2 \mathrm{~kg}$, pengurangan permukaan anatomi di posterior dan medial premaksila, penambahan soft liner di bagian anatomi dan lateral kiri premaksila, aktivasi ikatan ekstra oral. Selanjutnya pada kontrol ketujuh, tiga minggu berikutnya, berat badan bayi $5,45 \mathrm{~kg}$, pengurangan permukaan anatomi di bagian posterior dan medial premaksila, penambahan soft liner di bagian anatomi anterior dan lateral kiri premaksila, aktivasi ikatan ekstra oral, reposisi button lebih ke superior.

Dua minggu kemudian pada kontrol kedelapan, di usia 5 bulan 21 hari, berat badan bayi $5,5 \mathrm{~kg}$, permukaan anatomi di bagian posterior dan medial premaksila dikurangi, lalu ditambahkan soft liner di bagian anatomi anterior dan lateral kiri premaksila, penambahan ikatan ekstra oral pada button kanan dengan double elastic untuk menekan dan menarik premaksila ke medial. Selanjutnya si bayi dikonsul ke Bedah Mulut RSHS untuk penatalaksanaan labioplasti.

\section{PEMBAHASAN}

Kemampuan mengisap, menelan dan bernapas merupakan tiga keahlian dasar dalam pemberian makanan pada bayi dengan susu botol maupun menyusu air susu ibu.Gerakan mengisap membawa makanan ke dalam mulut dengan menciptakan tekanan secara bertahap. Tekanan positif terbentuk ketika puting ditekan sehingga mengeluarkan cairan untuk masuk ke rongga mulut. Tekanan negatif atau isapan terbentuk ketika rongga mulut yang tertutup sedikit membesar dan bolus makanan ditarik ke dalam mulut. Kelainan orofasial berpotensi untuk mengubah kemampuan mengisap dan mengubah tipe tekanan yang dapat diciptakan oleh bayi. ${ }^{4}$

Bayi penderita celah bibir dan langit-langit bermasalah terhadap keberhasilan terpenuhinya kebutuhan nutrisi, karena bayi sulit untuk mengisap susunya, karena lemahnya tekanan pengisapan dan sulitnya memeras air susu. Otot-otot pada regio bibirnya tidak dapat menekan dot susu. Langitlangit yang tidak tertutup membuat bayi makin sulit mengisap susu karena tekanan negatif intra oralnya sangat lemah. Prosthetics feeding aid membantu penutupan celah bibir dan langit-langit sehingga bayi dapat menekan dot botol dalam posisi yang stabil serta adanya kontak yang erat antara lidah dan langit-langitdi bagian posterior. ${ }^{5}$ Plat ini merupakan piranti yang dibentuk sesuai anatomi rahang dengan celahlangit-langitnyasehingga dapat menutup celah. Dengan mengembalikan kondisi rongga mulut dan hidung yang terpisah, membantu dalam pemberian makan. $^{4}$

Secara fungsional plat ini dimaksudkan untuk menormalisasi pemberian susu, posisi lidah dan menelan dengan menutup celah. Macam-macam prosthetics feeding aid ditinjau dari segi ortopedik yaitu tipe aktif yang secara aktif mereposisi letak segmen alveolus dengan menggunakan plat yang memakai per dan sekrup, dan tipe pasif yang menuntun pertumbuhan alveolar ke arah yang lebih baik.

Pada bayi dengan celah bibir dan langit-langit bilateral komplit disertai premaksilanya protrusif dilakukan prabedah ortopedik dengan menggunakan power chain yang dikaitkan ke button yang terdapat pada plat $\mathrm{Hotz}$ terbukti memperlihatkan efektivitas klinis untuk meretraksi maksila ke belakang dan ke bawah sehingga dapat dilaksanakan koreksi bedah. ${ }^{6}$ Ikatan ekstra oral dapat mengkompensasi gaya otot 
orbikularis oris yang terputus seolah-olah terjadi penyatuan otot sehingga dapat memperbaiki bentuk basis hidung dan posisi kolumela.

Pemasangan ikatan ekstra oral kombinasi karet elastik ortodonti dan hypapix dengan ukuran $4 \mathrm{~cm}$ sisi kiri kanan dan lebar $1 \mathrm{~cm}^{8}$ Karet elastik yang digunakan ukuran 5/16 dengan daya yang diberikan sebesar 2,5 oz, yang setara dengan $71 \mathrm{~g}$ berdasarkan besarnya daya tersebut dan panjang peregangan karet elastik sepanjang $12 \mathrm{~mm}$.

Beberapa hasil penelitan menunjukkan bahwa ketika piranti telah dipasangkan, secara umum bayi menghabiskan makanannya setengah dari waktu yang selama ini dibutuhkan. Selain itu volume susu yang dikonsumsi menunjukkan peningkatan hampir 2 kali lipat. Dengan kata lain terjadi peningkatan efisiensi pemberian makan dan pertambahan berat badan bayi.

Disimpulkan bahwa celah bibir dan langit-langit terjadi akibat gagalnya penyatuan rangka wajah bagian tengah pada minggu 4-10 masa kehamilan. Kelainan orofasial ini merupakan kelainan yang paling sering ditemui, berpotensi untuk mengubah kemampuan menghisap, menelan, tipe tekanan dan fungsi struktur mulut yang terlibat dalam proses asupan makanan pada bayi. Pada bayi celah bibir dan langit-langit bilateral komplit dengan segmen premaksila ke depan, rangkaian perawatan meliputi konstruksi pemasangan feeding prosthesis dengan memodifikasi penempatan ikatan ekstra oral untuk mereposisi segmen yang bergeser. Pemasangan piranti ini memperlihatkan efektivitas klinis untuk meretraksi maksila ke posterior dan inferior, piranti ini diperbaiki terus untuk mendapatkan ketepatan yang lebih baik hingga dapat dilaksanakan koreksi bedah.

Disarankan perawatan dini harus diberikan kepada bayi yang baru lahir dengan celah bibir dan langit-langit untuk memaksimalkan fungsi alami dari daya hisap dan penelanan yang sulit dan lengkung rahang yang lebih normal yang terbentuk pada usia dini akan mempengaruhi perkembangan struktur tulang wajah yang cenderung menghasilkan pola pertumbuhan normal.

\section{DAFTAR PUSTAKA}

1. Beumer J. Maxillofacial rehabilitation prosthodontic and surgical consideration. St. Louis: Ishiyaku Euro America, Inc.; 1996. p.234-40.

2. Neville BW. Oral and maxillofacial pathology. $2^{\text {nd }}$ Ed. Philadelphia: WB Saunders Co.; 2002. p.2-4.

3. Razek MKA. Prosthetics feeding aids for infant with cleft lip and palate. J Prosthet Dent 1980; 44 (5):556-61

4. Herzog C, Honigmann K. Give us a little time (how babies with cleft lip and palate can be breasfed). Medela AG.; 1996.p.10-1, 26-7.

5. Hotz MM, Gnoinsky WM. Effect of early maxillary orthopaedics in coordination with delayed surgery for cleft lip and palate. 1979. p.201-10.

6. Fiqueroa AA. Intraoral-appliance modification to retract the premaxilla in patients with bilateral cleft lip and palate. Craniofac J 1996; 33(6):497-500.

7. Hollman K. The Viennese concept for treatment of cleft lip, alveolus and palate. Bern: Huber; 1986. p.55-9.

8. Dahliana L. Pengaruh pemakaian strapping extra oral kombinasi karet elastik dan hypafix terhadap pengurangan lebar celah bibir dan deviasi kolumela pada pasien celah bibir dan langit-langit unilateral [Tesis]. Bandung: Fakultas Kedokteran Gigi Universitas Padjajaran; 2010. 